УДК 373.3.091.12.011.3-051:159.922-027.561

DOI:

Оксана Шквир, доктор педагогічних наук, доцент кафедри педагогіки Хмельницької гуманітарно-педагогічної академії Наталія Казакова, кандидат педагогічних наук, доцент кафедри педагогіки Хмельницької гуманітарно-педагогічної академії

\title{
АКМЕОЛОГІЧНИЙ ПІДХІД ДО СТУПЕНЕВОЇ ПІДГОТОВКИ МАЙБУТНІХ УЧИТЕЛІВ ПОЧАТКОВИХ КЛАСІВ
}

У статті акиентовано увагу на необхідності оновлення системи ступеневої підготовки майбутніх учителів початкових класів на засадах акмеологічного підходу. Уточнено сутність понять “акмеологія", “акмеологічний підхід”. Розкрито особливості ступеневої підготовки майбутніх учителів початкових класів з позичї акмеологічного підходу. Визначено внутрішні і зовнішні чинники досягнення майбутніми вчителями особистісного і професійного акме на кожному етапі підготовки. Наголошено на необхідності перезавантаження методичного інструментарію викладачів ЗВО акмеологічними способами навчання.

Ключові слова: ступенева підготовка; акмеологія; акмеологічний підхід; рівні освіти; майбутні учителі початкових класів.

תim. 9.

Oksana Shkvyr, Doctor of Sciences (Pedagogy), Associate Professor of the Pedagogy Department Khmelnytsky Humanitarian-Pedagogical Academy Nataliia Kazakova, Ph.D.(Pedagogy), Associate Professor of the Pedagogy Department Khmelnytsky Humanitarian-Pedagogical Academy

\section{ACMEOLOGICALAPPROACH TO THE STAGE TRAINING OF THE FUTURE PRIMARY SCHOOL TEACHERS}

The article focuses on the need to update the system of stage training of the future primary school teachers on the basis of the acmeological approach. The essence of the concepts "acmeology", "acmeological approach" has been specified. The peculiarities of the stage training of the future primary school teachers from the standpoint of acmeological approach have been revealed. It is noted that the acmeological approach appears as a strategic guideline that directs the educational process to the achievement of the future primary school teachers' summit in physical, spiritual, moral and professional development in accordance with each stage of education. It is determined that from the standpoint of acmeological approach stage training of the future primary school teachers is understood as a holistic system of successive, complementary stages of obtaining the pedagogical education, each of which raises the level of self-awareness, self-knowledge of the future teachers; mastering these techniques of self-education and self-upbringing on the basis of the productive positive "I" -concept that provides continuous general cultural and personal-professional self-development of the future teacher, the possibility of the further education, transition to the new quality of training. It is proved that the acmeological approach promotes the continuous advancement of the future teacher's personality to the highest achievements in professional activity, the ascent to certain summits, typical for the specific stage of higher education (professional junior bachelor, bachelor, master). The internal and external factors of achievement by the future teachers of personal and professional acme at each stage of preparation have been determined. An emphasis is placed on the need to reboot the methodological tools of teachers of higher education institutions by acmeological teaching methods. It is concluded that the acmeological approach allows in a new fashion to treat the analysis and solution of problems of higher education related to the self-realization of the personality at certain stages of training. It is noted that the issue of elaboration of the stage method of personal and professional development of the future primary school teachers in the sphere of higher education requires further scientific researches. teachers.

Keywords: stage training; acmeology; an acmeological approach; levels of education; future primary school

П остановка проблеми. В умовах євроінтеграційних процесів та реформування загальної середньої освіти виникає потреба в якісному оновленні системи ступеневої підготовки майбутніх учителів початкових класів, яка, відповідно до законів України “Про вищу освіту” (2014) та “Про фахову передвищу освіту” (2019), передбачає послідовну професійну підготовку майбутніх учителів за трьома рівнями: фахова передвища освіта, що здійснюється на базі 9 класів; перший (бакалаврський) рівень вищої освіти, що здобувається на базі фахового молодшого бакалавра або 11 класів та другий (магістерський) 


\section{АКМЕОЛОГІЧНИЙПДХІДДОСТУПЕНЕВОЇПІДГОТОВКИ МАЙБУТНІХУЧИТЕЛІВ ПОЧАТКОВИХ КЛАСІВ}

рівень вищої освіти, що здійснюється на базі бакалавра [4; 5]. Серед методологічних підходів, що сприяють підвищенню якості професійної підготовки майбутніх учителів початкових класів в умовах ступеневої освіти, визначаємо акмеологічний. Він спрямовує педагогічний процес на творчо-вершинну якість особистісного та професійного становлення майбутнього фахівця. На його основі можливе вивчення закономірностей і умов, що сприяють неперервному просуванню особистості майбутнього вчителя до найвищих досягнень у професійній діяльності, сходженню іiі на ті чи ті вершини, типові для конкретного ступеня вищої освіти (фаховий молодший бакалавр, бакалавр, магістр).

Аналіз останніх досліджень і публікацій. Дослідженню проблем професійної підготовки фахівців в умовах ступеневої освіти в останні роки приділяється належна увага, зокрема таким i аспектам, як методологічні основи ступеневої підготовки у системі неперервної професійної освіти (Н. Ничкало, Л. Романишина, С. Сисоєва та ін.); порівняльний аналіз ступеневої освіти за кордоном і в Україні (В. Козаков, Т. Кошманова, Л. Пуховська та ін.); технологічні аспекти системи ступеневої професійної освіти (Г. Козлакова, В. Луговий, П. Сікорський та ін.).

Науковцями проведено низку досліджень із проблем теоретико-методологічних засад професійної підготовки вчителів початкових класів (Т. Атрощенко, В. Желанова, О. Савченко та ін.); ступеневої освіти вчителів початкових класів (С. Власенко, Н. Кічук, Л. Хомич та ін.).

Останнім часом зросла кількість досліджень, присвячених проблемі акмеології освіти та впровадженню акмеологічного підходу до професійної підготовки вчителя, про що свідчать наукові праці О. Антонової, О. Бодальова, Н. Гузій, А. Деркача, О. Дубасенюк, Н. Кузьміної, С. Пальчевського, Л. Рибалко та ін.

Водночас встановлено, що наукових розвідок у напрямі реалізації акмеологічного підходу до ступеневої підготовки майбутніх учителів початкових класів недостатньо.

Мета статті полягає у висвітленні теоретичних засад ступеневої підготовки майбутніх учителів початкових класів з позиції акмеологічного підходу.

Виклад основного матеріалу дослідження. Поняття “акмеологія” походить від грецьких слів "акме" - вища точка, вершина, квітуча пора; i “логос" - вчення. Цей термін був введений до наукового обігу М. Рибніковим (1928). Під акме розуміється період розквіту особистості, найвищих іiї досягнень, коли людина проявляє свою зрілість в усіх сферах життєдіяльності і, передусім, у професійній. Це період максимального розвитку iii здібностей і обдарувань. Акме розглядається науковцями як феномен людської природи, вершини зрілості, багатовимірна характеристика стану дорослої людини, що охоплює певний період iii прогресивного розвитку, пов'язаного 3 професійними, особистісними та соціальними досягненнями $[1 ; 3 ; 6 ; 8]$.

Наукові передумови акмеології були розроблені ще 144 р. до н.е. Апполодором, представником Александрійської школи, який розглядав максимальну досконалість як вершину в розвитку діяльності. При цьому під акме мався на увазі такий стан індивідуума, при якому досягається вищий результат його діяльності (“зоряна година”), а не процес руху до цього стану. Апполодар, розвиваючи вчення про акме, позначив вищу точку розвитку як кульмінацію діяльності ввів латинське визначення акме як розквіт [1].

Сьогодні під акмеологією розуміють наукову дисципліну, що вивчає умови й закономірності просування людини до вершин ії̈ особистої зрілості та професійної діяльності [1]. О. Дубасенюк зазначає, що акмеологія - це наука, що вивчає розвиток людини на ступені дорослості досягнення нею вершин у розвитку іiі як природної істоти (індивіда), особистості і суб'єкта діяльності (головним чином професійної) [3]. О. Антонова уточнює, що акмеологію передусім слід розуміти як науку про досягнення професіоналізму [1], який ми розглядаємо як системне явище, що характеризує стан особистості і діяльності людини, умову досягнення нею найвищих показників в особистісно-соціальному розвитку, професійній діяльності та творчості. Поділяємо думку науковців про те, що чим вищий рівень професіоналізму, тим більше в ньому індивідуального й особистісного $[2 ; 6 ; 8]$

Теоретико-методологічні засади акмеології становлять педагогічна антропологія К. Ушинського (антропологічний підхід), психологічні основи людинознавства, розроблені Б. Ананьєвим (людинознавчий підхід), педагогічна акмеологія (Н. Кузьміна та ін.) [9, 69].

На сучасному етапі найбільш розробленими $\epsilon$ напрями акмеології, пов'язані $з$ дослідженням особистісно-професійного розвитку особистості:

- філософський (І. Зязюн, В. Кремень та ін.), який будується на парадигмі розвитку людської психіки у філогенетичному, онтологічному та гносеологічному аспектах;

- психологічний (Г. Балл, І. Бех, В. Семиченко, В. Рибалка та ін.), спрямований на розвиток ідей щодо духовності професіонала як засобу 


\section{АКМЕОЛОГІЧНИЙПДХІДДОСТУПЕНЕВОЇПІГОТОВКИ МАЙБУТНІХ УЧИТЕЛІВ ПОЧАТКОВИХ КЛАСІВ}

досягнення вершин власного життєвого шляху; психологічних механізмів, шляхів і способів особистісно орієнтованого виховання й самовиховання духовних і професійно важливих якостей цілісної особистості;

- педагогічний (В. Вакуленко, Н. Гузій, О. Пєхота, Г. Штомпель та ін.), підпорядкований досягненню вершин педагогічного професіоналізму різнобічними засобами стимулювання особистісного та фахового розвитку [8, 238].

Уважається, що акме припадає на період вікової дорослості, соціальної й особистісної зрілості людини [1]. Однак “акмеологія” досліджує людину як на ступенях довузівської підготовки, вибору майбутньої професії, так і в ході навчання в ЗВО від предмета до предмета, від курсу до курсу, від рівня фахової передвищої освіти до рівня вищої освіти. Стратегія формування професійного успіху багато в чому визначається правильним вибором професії та підготовки до неї. Усвідомлений і самостійний вибір сприяє ефективності професійного розвитку, натомість випадковий, неусвідомлений вибір у більшості своїй визначає стратегію пристосування до професійних вимог та професії загалом. Ситуація професійного вибору є мотиватором специфічної активності особистості, що обумовлює успішність підготовки суб'єкта професійної діяльності [6, 212]. Тому з позиції акмеологічного підходу важливим $є$ питання внесення конструктивних змін до системи профорієнтаційного відбору майбутніх учителів початкових класів, що уможливить досягнення ними високих результатів у підготовці.

Суть акмеологічного підходу до підготовки майбутніх фахівців полягає у вивченні особистості студента як цілісного феномена в єдності їі суттєвих сторін (індивід, особистість, індивідуальність, суб'єкт життєдіяльності); орієнтації його на постійний саморозвиток і самовдосконалення, мотивації високих досягнень, прагненні високих результатів, життєвих успіхів; організації творчої діяльності на всіх етапах його неперервної освіти, створенні необхідних умов для самореалізації його творчого потенціалу [1]. Стан зрілості не з'являється у людини відразу: від усієї попередньої іiі життєдіяльності залежить, якою підійде вона до етапу зрілості, що складатиме основу її особистості і які здібності, запас знань, умінь і навичок буде характеризувати їі як суб'єкта діяльності, коли вона стане дорослою [6].

У процесі ступеневої підготовки майбутніх учителів початкових класів акмеологічний підхід постає як стратегічний орієнтир, що спрямовує освітній процес на досягнення майбутніми вчителями вершин у фізичному, духовноморальному й професійному розвитку відповідно до кожного рівня освіти. Він дає змогу вивчати ступеневу підготовку майбутніх учителів початкових класів як цілісний процес, визначати шляхи педагогічної компенсації недосягнутого на попередньому етапі підготовки, моделювати траєкторії особистісно-професійного саморозвитку студентів відповідно до кожного ступеня освіти. Акмеологічний підхід передбачає створення на кожному етапі підготовки необхідних умов для розвитку в майбутніх учителів початкових класів уявлення про особистісний і професійний успіх. Він спрямовує майбутніх учителів на самовдосконалення в освітньому середовищі. У межах цього підходу окреслюються особливості наповненості ступеневої підготовки вчителя як професіонала; визначається, до якої педагогічної системи має бути включена особистість, щоб відбувався перехід від кульмінації до кульмінації в особистісному та професійному розвитку.

Відтак із позиції акмеологічного підходу ступеневу підготовку майбутніх учителів початкових класів розуміємо як цілісну систему послідовних, взаємодоповнювальних етапів здобуття педагогічної освіти, на кожному з яких відбувається підвищення рівня самосвідомості, самопізнання майбутніх учителів; оволодіння ними прийомами самоосвіти та самовиховання на основі продуктивної позитивної “' Я”-концепції, що забезпечує неперервний загальнокультурний i особистісно-професійний саморозвиток майбутнього вчителя, можливість його подальшого навчання, переходу до нової якості підготовки.

Внутрішніми чинниками досягнення майбутніми вчителями особистісного i професійного акме на кожному етапі підготовки $є$ високий рівень мотивації, потреба в досягненнях, прагнення до успіху та самовдосконалення, активність, цілеспрямованість, здатність мобілізувати свої можливості, позитивне мислення, віра в свої можливості. Зовнішніми чинниками вияву акме є сприятливе освітнє середовище, яке спонукає особистість до розкриття ії можливостей, самореалізації, а також позааудиторні заходи, які можуть стати поштовхом в особистісному і професійному розвитку [8].

Акмеологічний підхід до професійного становлення фахівця передбачає, що найважливішим критерієм досягнення вершин професіоналізму в будь-якому виді діяльності, що вимагає фахової освіти, $є$ компетентність, а в основі саморуху до вершин професіоналізму - система цінностей людини $[9,70]$. Відповідно до Професійного стандарту 


\section{АКМЕОЛОГІЧНИЙПДХІДДОСТУПЕНЕВОЇПІДГОТОВКИ МАЙБУТНІХ УЧИТЕЛІВ ПОЧАТКОВИХ КЛАСІВ}

\begin{abstract}
"Вчитель початкових класів закладу загальної середньої освіти” (2018), кожен етап підготовки в системі ступеневої освіти майбутніх учителів початкових класів має передбачати оволодіння ними певними трудовими функціями i професійними компетентностями [7]. Вони становлять складові професіоналізму майбутніх фахівців, якими має оволодіти майбутній вчительфаховий молодший бакалавр, вчитель-бакалавр і вчитель-магістр відповідно до принципів наступності і неперервності навчання. У процесі ступеневої підготовки майбутніх учителів початкових класів доцільним також $\epsilon$ ознайомлення здобувачів освіти зі змістом Професійного стандарту "Вчитель початкових класів закладу загальної середньої освіти”, із трудовими функціями вчителя, що уможливить їхню активність у здобутті професійних компетентностей та розуміння важливості професійного зростання в умовах ступеневої освіти.
\end{abstract}

Успішність досягнення вершин на кожному етапі підготовки залежить від умов, які будуть створені в ЗВО, а також методів, форм та засобів забезпечення ступеневої освіти. Важливо вчити майбутніх фахівців проєктувати і досягати “мікроакме", яке задає напрям і енергетизує їхню діяльність, наближаючи до кінцевої мети підготовки. Поділяємо думку О. Цюняк, що "мікроакме" складається 3 інтересу до професійної діяльності, позитивного емоційного тонусу, задоволеності вибором професії тощо, і $є$ спрямовуючим вектором на досягнення вершин на кожному рівні освіти ступеневої підготовки майбутніх учителів $[8,237]$. Фундаментальною умовою розвитку інтегральних характеристик особистості професіонала $є$ також усвідомлення ним необхідності зміни, перетворення свого внутрішнього світу та пошук нових можливостей самореалізації у професії. Проте подібної професійної самосвідомості недостатньо, необхідний запуск механізмів саморегуляції та самоосвіти $[6,213]$. Тому викладачам необхідно перезавантажувати методичний інструментарій акмеологічними способами навчання, до яких, до прикладу, відносимо мозковий штурм, сократів діалог, метод проєктів, кейс-метод, робота в малих групах, тренінги, коментування думок, проблемне навчання, оцінка (або самооцінка) дій учасників та ін.

Висновки та перспективи подальших досліджень. Отже, акмеологічний підхід орієнтує майбутніх учителів початкових класів на постійний саморозвиток; сприяє усвідомленню ними необхідності досягнення вершин професіоналізму; дає змогу по-новому підійти до аналізу та розв'язання проблем ступеневої освіти, пов'язаних із самореалізацією особистості на певних етапах професійної підготовки.

Подальший науковий пошук слід спрямувати на розробку поетапної методики особистіснопрофесійного розвитку майбутніх учителів початкових класів у площині ступеневої освіти.

\section{ЛІТЕРАТУРА}

1. Антонова О. С. Акмеологічний підхід до визначення сутності педагогічної обдарованості. Акмеологія - наука ХХІ століття: матеріали III Міжнар. наук.-практ. конфер. За ред. В. О. Огнев'юка. Київ: Київськ. ун-т імені Бориса Грінченка, 2011. С. 17 - 22.

2. Драч I. I. Акмеологічний підхід до формування професійної компетентності студентів у вищому навчальному закладі. URL : http://tme.umo.edu.ua/ docs/2/09drachs.pdf (дата звернення: 17.02.2021).

3. Дубасенюк О. А. Акмеологічний підхід як стратегічний орієнтир особистісно-орієнтованої педагогічної освіти. Проблеми освіти: збірник наукових пращь. Вип. 84. Житомир-Київ, 2015. C. $25-30$.

4. Закон України "Про вищу освіту": прийнятий 01.07.2014 p. URL : http://zakon2.rada.gov.ua/laws/ show/1556-18 (дата звернення: 16.02.2021).

5. Закон України "Про фахову передвищу освіту": прийнятий 06.06.2019 p. URL : https:// zakon.rada.gov.ua/laws/show/2745-19 (дата звернення: 16.02.2021).

6. Міненок А. Акмеологічний підхід у процесі професійно-творчого саморозвитку майбутнього вчителя початкової школи. Витоки педагогічної майстерності. 2015. Вип. 15. С. 210 - 216.

7. Професійний стандарт "Вчитель початкових класів закладу загальної середньої освіти": затверджений наказом Міністерства соціальної політики України від 10.08.2018 p. № 1143. URL : https://zakon.rada.gov.ua/rada/show/v1143732-18 (дата звернення: 19.02.2021).

8. Цюняк О. П. Реалізація акмеологічного підходу у професійній підготовці майбутніх магістрів початкової освіти до інноваційної діяльності. URL : http://lib.pnu.edu.ua:8080/ bitstream/123456789/8883/1/Основна \%20стаття _Цюняк\%20О.П..pdf(дата звернення: 18.02.2021).

9. Шквир О. Л. Ступенева підготовка майбутніх учителів початкової школи до проведення педагогічних досліджень: моногр. Житомир: Видво ЖДУ ім. І. Франка, 2018. 500 с.

\section{REFERENCES}

1. Antonova, O. Ye. (2011). Akmeolohichnyi 
pidkhid do vyznachennya sutnosti pedahohichnoyi obdarovanosti [Acmeological approach to determining the essence of pedagogical talent]. Akmeolohiia nauka XXI stolittia: materialy III Mizhnar. nauk.prakt. konfer - Acmeology - the science of the XXI century: Proceedings of the III International Scientific-Practical Conference. Under the editorship of V. O. Ohneviuk. (pp. 17 -22). Kyiv. [Ukrainian].

2. Drach, I. I. Akmeolohichnyy pidkhid do formuvannya profesiynoyi kompetentnosti studentiv u vyshchomu navchalnomu zakladi [Acmeological approach to the formation of professional competence of students in higher education]. Available at: http:// tme.umo.edu.ua/docs/2/09drachs.pdf (Accessed 17 Feb. 2021). [in Ukrainian].

3. Dubaseniuk, O. A. (2015). Akmeolohichnyy pidkhid yak stratehichnyy oriyentyr osobystisnooriyentovanoyi pedahohichnoyi osvity [Acmeological approach as a strategic landmark of personalityoriented pedagogical education]. Problems of education: collection of scientific works. Vol. 84. Zhytomyr-Kyiv, pp. 25 - 30. [in Ukrainian].

4. Zakon Ukrainy "Pro vyshchu osvitu" [Law of Ukraine "On Higher Education"] adopted on July 1, 2014. Available at: http://zakon2.rada.gov.ua/laws/ show/1556-18 (Accessed 16 Feb. 2021). [in Ukrainian].

5. Zakon Ukrainy "Pro fakhovu peredvyshchu osvitu" [Law of Ukraine "On Professional Higher Education"] adopted on June 6, 2019. Available at: https://zakon.rada.gov.ua/laws/show/2745-19 (Accessed 16 Feb. 2021). [in Ukrainian].
6. Minenok, A. (2015). Akmeolohichnyi pidkhid u protsesi profesiino-tvorchoho samorozvytku maibutnioho vchytelia pochatkovoi shkoly [Acmeological approach in the process of professional and creative self-development of the future primary school teacher]. The origins of pedagogical skills. Vol. 15. pp. $210-216$. [in Ukrainian].

7. Profesiinyi standart "Vchytel pochatkovykh klasiv zakladu zahalnoi serednioi osvity" [Professional standard "Primary school teacher of general secondary education institution"] approved by the order of the Ministry of Social Policy of Ukraine dated August 10, 2018 No.1143. Available at: https://zakon.rada.gov.ua/rada/show/ v1143732-18 (Accessed 19 Feb. 2021). [in Ukrainian].

8. Tsiuniak,O. P. Realizatsiia akmeolohichnoho pidkhodu u profesiinii pidhotovtsi maibutnikh mahistriv pochatkovoii osvity do innovatsiinoi diialnosti [Implementation of the acmeological approach in the professional training of the future masters of primary education for innovation]. Available at: http:// lib.pnu.edu.ua:8080/bitstream/123456789/8883/1/ Основна \% 20 стаття_Цюняк\% $200 . П . p d f$ (Accessed 18 Feb. 2021). [in Ukrainian].

9. Shkvyr, O. L. (2018). Stupeneva pidhotovka maibutnikh uchyteliv pochatkovoi shkoly do provedennia pedahohichnykh doslidzhen [Stage preparation of the future primary school teachers for pedagogical research]. Zhytomyr, 500 p. [in Ukrainian].

Стаття надійшла до редакції 08.01.2021

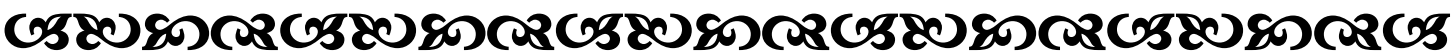

“Величезна виховна сила школи народжується там, де в людини відқривається життя, є улюблений учитель”.

Василь Сухомлинський педагог, публічист, письменник, поет

"Виховання є мистеитвом, використання яқого зростатиме протягом багатьох поколінь".

Іммануїл Кант

німеиький бөілособ

“Бути гарним педагогом - ие бути справжнім реборматором майбутнього життя України, бути апостолом Травди і Науки".

Cogбія Русова педагог

\section{G5808nc2058080}

Молодь і ринок №2 (188), 2021 